\title{
Egy oktatóprogram fejlesztésének lehetőségei tüdőgyógyász szakorvosok krónikus obstruktív tüdőbetegséggel kapcsolatos megítélése alapján
}

\author{
Oláh Máté dr. ${ }^{1}$ - Kresznerits Szilvia ${ }^{2}$ - Kun Csaba dr. ${ }^{3}$ \\ Perczel-Forintos Dóra dr. ${ }^{2}$ - Csánky Eszter dr. ${ }^{3}$ - Mészáros Ágnes dr. ${ }^{1}$

\footnotetext{
${ }^{1}$ Semmelweis Egyetem, Egyetemi Gyógyszertár és Gyógyszerügyi Szervezési Intézet, Budapest

${ }^{2}$ Semmelweis Egyetem, Általános Orvostudományi Kar, Klinikai Pszichológia Tanszék, Budapest Tüdőgyógyászati Osztály, Miskolc
} \\ ${ }^{3}$ Borsod-Abaúj-Zemplén Megyei Központi Kórház és Egyetemi Oktatókórház, Semmelweis Tagkórház,
}

\begin{abstract}
Bevezetés: A krónikus obstruktív tüdőbetegség jelentős egészségügyi teher mind a beteg, mind a társadalom részére. Betegoktatással ez a teher csökkenthető, így magyar környezetben kerestük az optimális tartalmat ehhez.

Célkitüzés: 1) A tüdőgyógyászok véleményére épülő betegoktatási tartalom tervezése; 2) a tüdőgyógyászok magatartásának és percepcióinak megismerése; 3 ) a beteg adherenciája (együttmúködése) javítási lehetőségeinek felmérése. Módszer: Országszerte 20 gondozóban, kórházban és rehabilitációs központban dolgozó tüdőgyógyásszal készítettünk interjút. A struktúrát úgy alakítottuk ki, hogy egy betegoktató program kulcselemeit definiáljuk, valamint hogy teret engedjünk a percepciók, terápiás attitűdök felfedésének.

Eredmények: Az átlagos krónikus obstruktív tüdőbeteg dohányos, férfi, alulszocializált, köhög, fullad, és 40 évnél idősebb. Betegségét nem veszi komolyan, csak súlyosabb esetben fordul orvoshoz, adherenciája is csak ekkor nő meg. Ez a hatás gyakran átmeneti, csak a rosszullétre korlátozódik. Az adherencia szerint három csoport különíthető el: marginális jó adherencia (kb. 10\%) mellett az átlag 30-40\% között van, és a betegek jelentős része (60\%) minimális adherenciával bír. Az inhalátor használata ideális esetben maximum 3 lépésből áll, könnyen reprodukálható és elmagyarázható.

Következtetés: Az oktatóprogram keretét meghatározó szempontok a megfelelő betegkép (személyre szabás), a tüdőgyógyászati, helyszíni oktatás, az orvos-beteg kapcsolat, a betegek hozzáállása és az életmódbeli változtatások (leszokás a dohányzásról), valamint a megfelelő inhalátor kiválasztása.
\end{abstract}

Orv Hetil. 2020; 161(3): 95-102.

Kulcsszavak: betegoktatás, adherencia, krónikus obstruktív tüdőbetegség (COPD), percepció, attitűd

\section{Aspects of developing an education programme based on pulmonologists' appraisal related to chronic obstructive pulmonary disease}

Introduction: Chronic obstructive pulmonary disease (COPD) is a health burden for the patient and the society. We have sought to find the optimal education content to alleviate this burden.

Aim: (1) To create patient education content based on the pulmonologists' opinion; (2) to understand the pulmonologists' attitudes and perceptions; (3) to evaluate the options to improve patient adherence.

Method: We have performed 20 interviews with pulmonologists working in inpatient, outpatient and rehabilitation settings. The structure of the interviews has been designed to determine the key elements of a patient education programme and to discover perception and therapeutic attitudes.

Results: The average COPD patient is a smoker, male, under-socialized, coughs, has dyspnoea and is older than 40 years. He does not take his illness seriously, and seeks medical attention only in case of worsening of the disease, and improvement in adherence is only present in such cases. The latter phenomenon is frequently transient, and limited to worse periods. Three adherence groups can be defined: marginal good adherence (approx. 10\%), the average is 
around $30-40 \%$, and minimal adherence (60\%). Correct inhaler use should be taught in maximum three steps, which should be easily reproduced and explained.

Conclusion: The aspects defining the framework of the education programme are the adequate patient profile (tailormaking), on-the-spot education in the pulmonology centre, the relationship between the patient and the doctors, patient attitudes and lifestyle changes (smoking cessation), and choosing the adequate inhaler.

Keywords: patient education, adherence, chronic obstructive pulmonary disease (COPD), perception, attitude

Oláh M, Kresznerits Sz, Kun Cs, Perczel-Forintos D, Csánky E, Mészáros Á. [Aspects of developing an education programme based on pulmonologists' appraisal related to chronic obstructive pulmonary disease]. Orv Hetil. 2020; l61(3): 95-102.

(Beérkezett: 2019. augusztus 13.; elfogadva: 2019. szeptember 1.)

\section{Rövidítések}

COPD $=($ chronic obstructive pulmonary disease $)$ krónikus obstruktív tüdőbetegség; $\mathrm{FEV}_{1}=$ (forced expriration volume in 1 second) erőltetett kilégzés másodperctérfogata; GOLD = (Global Initiative for Chronic Obstructive Lung Disease) COPD nemzetközi irányelv; WHO = (World Health Organization) Egészségügyi Világszervezet

A krónikus obstruktív tüdőbetegség (chronic obstructive pulmonary disease - COPD) megelőzhető és kezelhető népbetegség, amelyet hosszan fennálló, progresszíven romló légúti obstrukció jellemez; döntően 40 év felett jelentkezik [1]. Jellemzője a krónikus gyulladás és a hörgőszúkület, amelyek gyakran a dohányzás következtében alakulnak ki [2]. A betegség során időnként állapotromlások, exacerbatiók jelentkeznek [3], melyek gyakorisága és a tünetek súlyossága az adherenciával negatív korrelációt mutat [2].

A compliance kifejezi, hogy a beteg mennyiben tartja be a javasolt gyógyszeres terápia időtartamát, a javasolt gyógyszer(ek) dózisát és azok alkalmazási gyakoriságát; a gyógyszerszedés pontosságáról ad felvilágosítást [4]. Az Egészségügyi Világszervezet (World Health Organization - WHO) szerint az adherencia „az egyén egészségügyi szakemberrel egyeztetett ajánlásoknak megfelelő viselkedése a gyógyszerszedés, a diéta és az életmódváltozás területén" [5], míg egy másik forrás szerint adherenciáról beszélünk, ha az egyén a terápiás folyamatban a gyógyszerszedéssel és/vagy életmód-változtatással az egészségügyi ellátás ajánlásai szerint együttmúködik [6]. Míg a compliance elsősorban az orvosi utasítások betartására szorítkozik, az adherencia a beteg együttmúködésének jellemzője, a továbbiakban ezt használjuk.

A WHO megújuló ajánlásai részletes javaslatokat tartalmaznak a COPD-s betegek kezelésével kapcsolatban, ezek megjelennek a mindennapi terápia során is. Magyarországon speciális helyzet alakult ki: míg a világ legnagyobb részén a háziorvosi rendszer kezeli és gondozza a COPD-s betegeket [7], addig a magyar beteg ellátása, gondozása a szakorvosi hálózatra, elsősorban a tüdőgondozókra hárul [7]. A tüdőgondozóban a szakorvos és a légzőszervi szakasszisztens együttesen végzi a beteg ellá- tását, oktatását. Ezt elősegítendő olyan programra van szükség, amely a beteget is motiválni képes arra, hogy segítse saját állapota javulását [8]. A dohányzásról leszoktató programok, a prevenció és a hatékony kezelés menedzsmentjének hármasa szükséges ahhoz, hogy a betegséget költséghatékony módon kezeljük [9].

A szakellátás előnyei elvitathatatlanok, az adherencia szempontjából viszont a háziorvosi ellátási rendszer közvetlenebb kapcsolatai jelentenek előnyt. Ezért tartottuk speciálisan fontosnak a magyarországi tüdőgyógyász szakorvosok véleményének felmérését a COPD-s betegek adherenciáját elősegítő magyarországi program kialakításában.

\section{Célkitüzés}

1) Elsősorban célunk egy olyan betegoktató programot létrehozni, amely figyelembe veszi a COPD-s betegek gondozásában kulcsszerepet játszó tüdőgyógyász szakorvosok véleményét.

2) Másodsorban célunk a tüdőgyógyász percepcióit és attitúdjét megismerni, amelyek átfogó képet adnak a betegképről, a kezelés sikeréről és az adherencia gondozásának jelenlegi helyzetéről.

3) Harmadsorban célunk volt annak felmérése, hogy a betegadherencia javításának milyen lehetőségei vannak tüdőgondozói és kórházi körülmények között.

\section{Módszer}

Összesen 20 pulmonológus szakorvossal készítettünk interjút, akik a COPD-s betegek ellátásában részt vesznek; tüdőgondozóban, kórházban és rehabilitációs centrumokban dolgoznak. Egy interjú 30 percig tartott, és összesen három nagy kérdéscsoportot vizsgáltunk.

Az 1. táblázat részletesen leírja a módszertani blokkok tematikáját. Fontos kiemelni, hogy ezek sorrendje megfelel a tanulmány célkitǔzéseinek, a tényleges interjúfelvétel során ettől sorrendbeli eltérés lehet (például a kezelés jellemzőiről és a COPD általánosságairól szóló részt előrevettük, ezzel beindítva a beszélgetést). 
Az interjúkat vegyes módszerrel készítettük, írásban rögzítettük óket. A félig strukturált kérdéscsoportok mellett igyekeztünk hagyni kibontakozni az orvosok véleményét, így összességében átmenet történt a mélyinterjú-módszertan felé [10]. Elsősorban a saját gondolatok és percepciók kibontását céloztuk, és valamennyi esetben rögzítettük a tüdőgyógyász által használt különös kifejezéseket is.

1. táblázat |Az interjúk módszertana és a célok szerinti megfelelés

\begin{tabular}{|c|c|c|}
\hline Cél & Téma & Mintakérdések \\
\hline \multirow[t]{5}{*}{1.} & \multirow[t]{5}{*}{$\begin{array}{l}\text { Az oktatóprogram } \\
\text { kérdései }\end{array}$} & $\begin{array}{l}\text { Hogyan élik meg a betegek a COPD-t? } \\
\text { Mi zavarja őket a leginkább? }\end{array}$ \\
\hline & & $\begin{array}{l}\text { Hogyan néz ki egy ideális oktatóprog- } \\
\text { ram az Ön betegei számára? }\end{array}$ \\
\hline & & $\begin{array}{l}\text { Milyen kulcselemeket említene, } \\
\text { amelyeket mindenképpen megtanítana } \\
\text { a betegnek? }\end{array}$ \\
\hline & & $\begin{array}{l}\text { Mit jelent az Ön számára az orvos- } \\
\text { beteg együttmúködés? }\end{array}$ \\
\hline & & $\begin{array}{l}\text { Mit tehet a tüdőgyógyász, a háziorvos, } \\
\text { a gyógyszerész és az oktatást végző? } \\
\text { Hogyan? }\end{array}$ \\
\hline \multirow[t]{5}{*}{2.} & \multirow[t]{5}{*}{$\begin{array}{l}\text { A betegek jellemzői } \\
\text { és a tüdőgyógyász } \\
\text { percepciói }\end{array}$} & $\begin{array}{l}\text { Mik a tapasztalatai a tüdőgyógyászaton } \\
\text { jelentkező betegekkel? } 10 \text { betegbőll } \\
\text { hány kapott már COPD-diagnózist? }\end{array}$ \\
\hline & & $\begin{array}{l}\text { Milyen állapotban vannak az Ön } \\
\text { betegei? }\end{array}$ \\
\hline & & $\begin{array}{l}\text { Mi az Ön legfőbb motivációja a } \\
\text { kezelést illetően? }\end{array}$ \\
\hline & & $\begin{array}{l}\text { Hogyan jellemezne egy tipikus } \\
\text { COPD-s beteget? }\end{array}$ \\
\hline & & Milyen a jó kezelés? \\
\hline \multirow[t]{5}{*}{3.} & \multirow{5}{*}{$\begin{array}{l}\text { Az adherencia és } \\
\text { javítása a tüdőgyó- } \\
\text { gyászaton }\end{array}$} & $\begin{array}{l}\text { Ön szerint mi befolyásolja a leginkább } \\
\text { a beteg együttmúködését? }\end{array}$ \\
\hline & & $\begin{array}{l}\text { Hogyan érdemes belégzőt választani a } \\
\text { betegnek? }\end{array}$ \\
\hline & & $\begin{array}{l}\text { Ki dönthet a belégzőról? Mik a patikai } \\
\text { generikus helyettesítés szempontjai? }\end{array}$ \\
\hline & & $\begin{array}{l}\text { Milyen módszereket használ a } \\
\text { tüdőgyógyászati gyakorlatban, amelyek } \\
\text { elősegítik a betegadherenciát? }\end{array}$ \\
\hline & & $\begin{array}{l}\text { Mit tehet a tüdőgondozó a beteg } \\
\text { adherenciájának javításáért? }\end{array}$ \\
\hline
\end{tabular}

COPD = krónikus obstruktív tüdőbetegség

\section{Eredmények}

\section{A vizsgált populáció}

A mélyinterjút 20 tüdőgyógyász szakorvossal végeztük el. A szakmában dolgozók többsége 50 év fölötti, nagyrészt tüdőgondozóban dolgoznak (2. táblázat). A Magyar Tüdőgyógyász Társaság véleménye szerint [11] 540 aktív tüdőgyógyász szakorvos dolgozik az országban, s csaknem 50\%-uk betöltötte az 55. életévét. Az interjúalanyokat úgy választottuk ki, hogy nemi, életkori és munkahelyi megoszlásuk megfeleljen a magyar tüdőgyógyászok megoszlásának. A teljes minta mintegy 4\%-a nyilatkozott az interjúink során.

2. táblázat |A tüdőgyógyászok $(n=20)$ neme, munkahelye és kora

\begin{tabular}{llrc}
\hline & & Fő & $\%$ \\
\hline \multirow{2}{*}{ Nem } & Férfi & 3 & $15 \%$ \\
& Nő & 17 & $85 \%$ \\
\hline \multirow{2}{*}{ Fő munkahely } & Kórház & 7 & $35 \%$ \\
& Tüdőgondozó & 12 & $60 \%$ \\
& Rehabilitáció & 1 & $5 \%$ \\
\hline \multirow{2}{*}{ Kor } & 40 alatt & 3 & $15 \%$ \\
& $40-50$ & 8 & $40 \%$ \\
& 50 fölött & 9 & $45 \%$ \\
\hline
\end{tabular}

\section{A betegek jellemzôi és a tüdőgyógyász percepciói}

Arra kértük az orvosokat, hogy jellemezzék az általuk gondozott COPD-s betegeiket, említsenek olyan jeleket, megfigyeléseket, amelyekból azonnal el tudják dönteni, hogy COPD-s beteggel van dolguk. Sok hasonló elem jelent meg: „dohányos”, „alulszocializált”, „köhög, fullad, lassú”, „idősebb”, „férfi”. Megfigyeltük a tankönyvi emphysemás/bronchitises típus szétválasztását is. Az egyik tüdőgyógyász képletesen úgy jellemezte a két típust, hogy „van a sovány, szikár, bagós”, száraz típus, valamint a „köpködős, korpulens, szuszogós”, aki pedig a szaftos. Az egyik véleményalkotó azt mondta, hogy most már talán több nő van, mert a korábbi dohányreklámoknak köszönhetően elhitették a hölgyekkel, hogy dohányozni sikk. Ez az emancipáció elsősorban Budapestre és környékére összpontosul, itt 1 : l arányban lát COPD-s férfiakat és nóket a szakellátás. A betegség szocioökonómiai gradienssel is párosul: a betegek alacsonyabban szocializáltak, vidéken még több a férfi, mint a nő, mivel a nők gyakrabban kapnak „előkelőbb” asztmadiagnózist (1. ábra).

A COPD diagnosztizáltságának számszerű felméréséhez megkérdeztük: mit gondolnak, 10 betegból hány fó van már az ellátórendszerben a megfelelő diagnózissal? Az eredmények szerint 10 betegból átlagosan 4,2 diagnosztizált (szórás = 1,7), az értékek 2 és 10 között szóródtak.

A tüdőgyógyászi vélemények szerint az „éberség” kialakításának van jelentősége, hiszen jócskán van még diagnosztizálatlan beteg. A betegek későbbi stádiumban jelentkeznek, és csak súlyos panaszok hívják fel a figyelmet a betegség jelenlétére. Gyakran pedig társrendelésről érkezik a beteg, vagyis a COPD komorbiditásként 
Köhög, fullad, köpetes, lassú Dohányos

Alacsony szocioökonómiai státusz

Férfi

50 év feletti

Sovány, szikár, szárazan köhögő

Ajakcianózis

Mind más/stádium függő

Keveset mozog, mozgásra fullad

Felülbírál, kötekszik

Túlsúlyos

Nyugdíjas

Nő

\begin{tabular}{l|l} 
1. ábra & $\begin{array}{l}\text { A COPD-s betegek profilja } \\
\text { COPD }=\text { krónikus obstruktív tüdóbetegség }\end{array}$
\end{tabular}

kerül felfedezésre (2.ábra). A véleményekben megjelennek a „panasz hozza be”, „légúti infekció” "FEV $\mathrm{FEV}_{1}<50 \%$ ” és a „családtagot zavaró (fáradékonyság/köhögés)” szavak. Tehát a tünetesség az, ami elsősorban zavarja a beteget vagy családtagját, és a diagnózis irányába tereli. „Nehezen vezethető”, „többszöri találkozás kell”, a „legrosszabb” adherenciával rendelkezik. A helyszínen még szófogadónak túnik, később viszont spórol a gyógyszerrel, vagy szükség esetén többször használja az inhalátorát, elsősorban a rohamoldót. A cardiovascularis betegekkel ellentétben a COPD-s beteg alacsonyabb adherenciával bír [6], vagy nem érzi krónikusnak a betegséget, ezért pánikszerúen kezeli. Ehhez hozzájárul, hogy korai stádiumban bagatellizálják a betegségüket, nem veszik komolyan sem a dohányzásról való leszokást, sem a javasolt terápiát.
A betegségelfogadás nem megfelelő: a tüdőbetegségekre egyfajta átmeneti „infekcióként” tekintenek, és nem foglalkoznak vele. Anyagi problémák is előfordulnak a betegnél, így a terápia a legolcsóbb, rohamoldó komponens felé irányul. Megjelent egyetlen pozitív vélemény is: a diagnóziskor még lehangolt a beteg, de amikor a második találkozáskor elégedett a gyógyszerrel, már jobban elfogadja a terápiát. Az inhalátorra a beteg gyakran nem gyógyszerként tekint, hanem „gyógypipaként" említi.

\section{Az adherencia és javitása a tüdögyógyászaton}

Az adherencia megítélése COPD-ben az átlagosnál roszszabb: a vegyes és az átlagnál rosszabb kategóriák vezetnek. A tünetes betegek adherensebbek, de ez a hatás átmeneti: csak addig szedik a gyógyszert, amíg rosszul vannak (3. ábra).

Az interjúkban a betegségpercepcióra többször visszatértek az alanyok, kiemelve, hogy az enyhe stádiumú, tünetmentes beteg „nem veszi komolyan” betegségét, a tünetes „gyógyulni akar”, ugyanakkor a dohányzás és a COPD közötti összefüggést nem érzi. A betegek inkább úgy nyilatkoznak, hogy szívesebben szedik a gyógyszert és folytatják a dohányzást, de elutasítják a leszokás lehetőségét. Gyakran a környezetet és a légszennyezést jelölik meg mint a betegség okát. A megkérdezett orvosok elmondták, hogy „nagyon nehéz elkezdeni a terápiát”, a „súlyos állapotú betegekkel van könnyebb dolguk”. Ugyanakkor tudni kell azt is, hogy minden kategóriában vannak jó adherenciával bíró ,jól neveltek” is.

Az egyik vélemény szerint három csoportba érdemes sorolni a COPD-s betegeket az adherencia szerint: van,
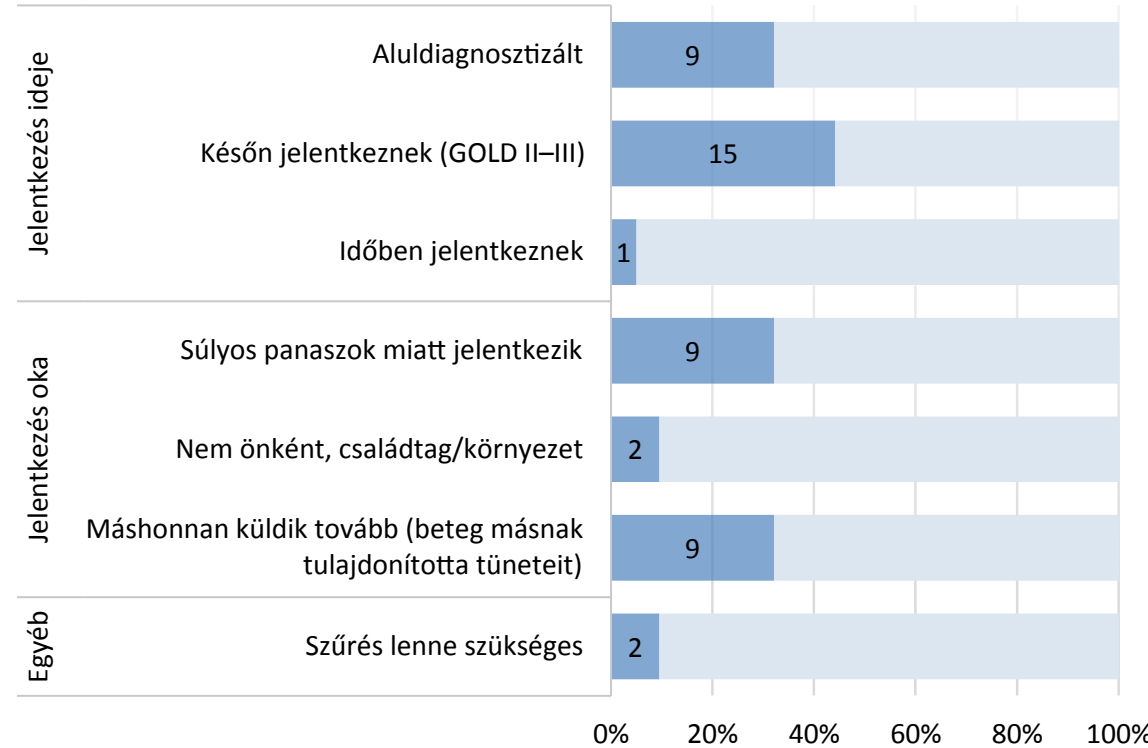

\begin{tabular}{l|l} 
2. ábra & $\begin{array}{l}\text { A COPD diagnosztizáltsága és annak körülményei } \\
\text { COPD }=\text { krónikus obstruktív tüdóbetegség; } \text { GOLD = COPD nemzetközi irányelv }\end{array}$
\end{tabular} 

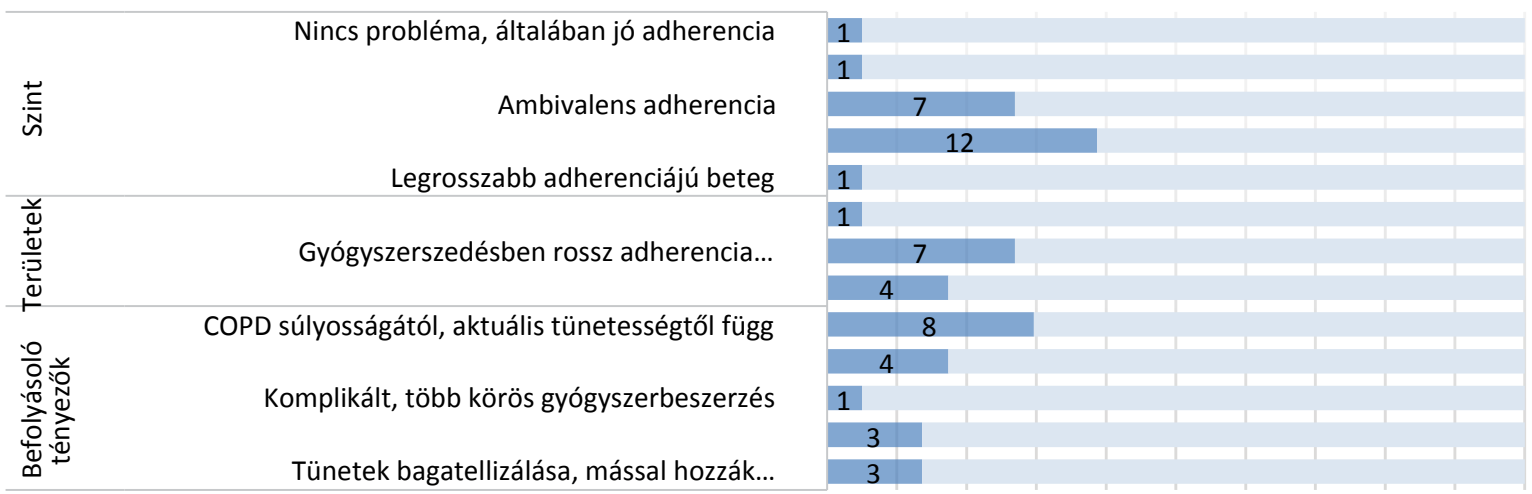

$\begin{array}{lllllllllll}0 \% & 10 \% & 20 \% & 30 \% & 40 \% & 50 \% & 60 \% & 70 \% & 80 \% & 90 \% & 100 \%\end{array}$

3. ábra

$\mid \begin{aligned} & \text { A COPD-s betegek adherenciája és jellemzői } \\ & \text { COPD = krónikus obstruktív tüdőbetegség }\end{aligned}$

akinek minimális az adherenciája (kb. 60\%), velük nem lehet vagy nagyon nehéz eredményt elérni. A ,jó” adherencia kb. 30-40\%-ot jelent (évi max. 6 kiváltás). Nagyon szúk az a réteg, amelyik a „tökéletes adherenciájú” csoportba tartozik (évi 10 kiváltás fölött, 12 hónapra számítva, 10\%). Egy másik vélemény szerint az COPD-s adherencia $20 \%$ körül van, és kiemeli azon betegoktató programok szerepét, akik elősegítik az inhalátorhoz való ragaszkodást, valamint annak helyes használatát.

A generikus készítmények és eszközök kapcsán felmértük a tüdőgyógyászok nyitottságát arra, hogy a patikában olcsóbb gyógyszerre cserélje a gyógyszerész a felírtat (azonos hatóanyag mellett). A vélemények egybehangzók: a hatóanyag és a beviteli mód megválasztása teljes egészében szakorvosi feladat, kifejezetten nemkívánatos a patikai inhalátorcsere. Két interjúalany fogalmazott meg ettől eltérő álláspontot: a beteg kérésére elképzelhetőnek tartja a patikai eszközcserét, abban az esetben, ha az ára kétezer forint alatt van. Ezek szerint ez az összeg egy lélektani határ lehet, amennyit a beteg haj- landó még rákölteni a COPD gyógyszerére. Egy másik vélemény elképzelhetoonek tartja, hogy a gyógyszerész döntsön az inhalátor típusáról, mivel az egyes hatóanyagok esetén azonos klinikai hatás érhető el a különböző inhalátortípusokból, és a hatóanyag az elsődleges. Ebben az esetben havi szintü betegmonitorozásra van szükség, és a tüdőgyógyászati kezelést a gyógyszerész-háziorvos-pulmonológiai asszisztens hármasában, integrált szemléletben kell elképzelni [12].

$\mathrm{Az}$ adherenciát vezető tényezők között kiemelkedik a betegség súlyossága, a gyógyszer „használhatósága”, az ára, a betegségbelátás és az orvos-beteg kapcsolat (kommunikáció). Ezek közül kettő a betegnek a vizsgálat során nem változó paramétere (az iskolázottság nem változtatható, bár ennek kivetülése, a betegségbelátás igen; a COPD stádiuma adott, a tünetesség és az exacerbatiokontroll javítható), ugyanakkor a beteggel való kapcsolat és a kommunikáció, valamint a gyógyszer „használhatóságával" kapcsolatos percepciók fontos bemeneti elemei a betegoktató tartalomnak (4. ábra). Az adherenciát be-

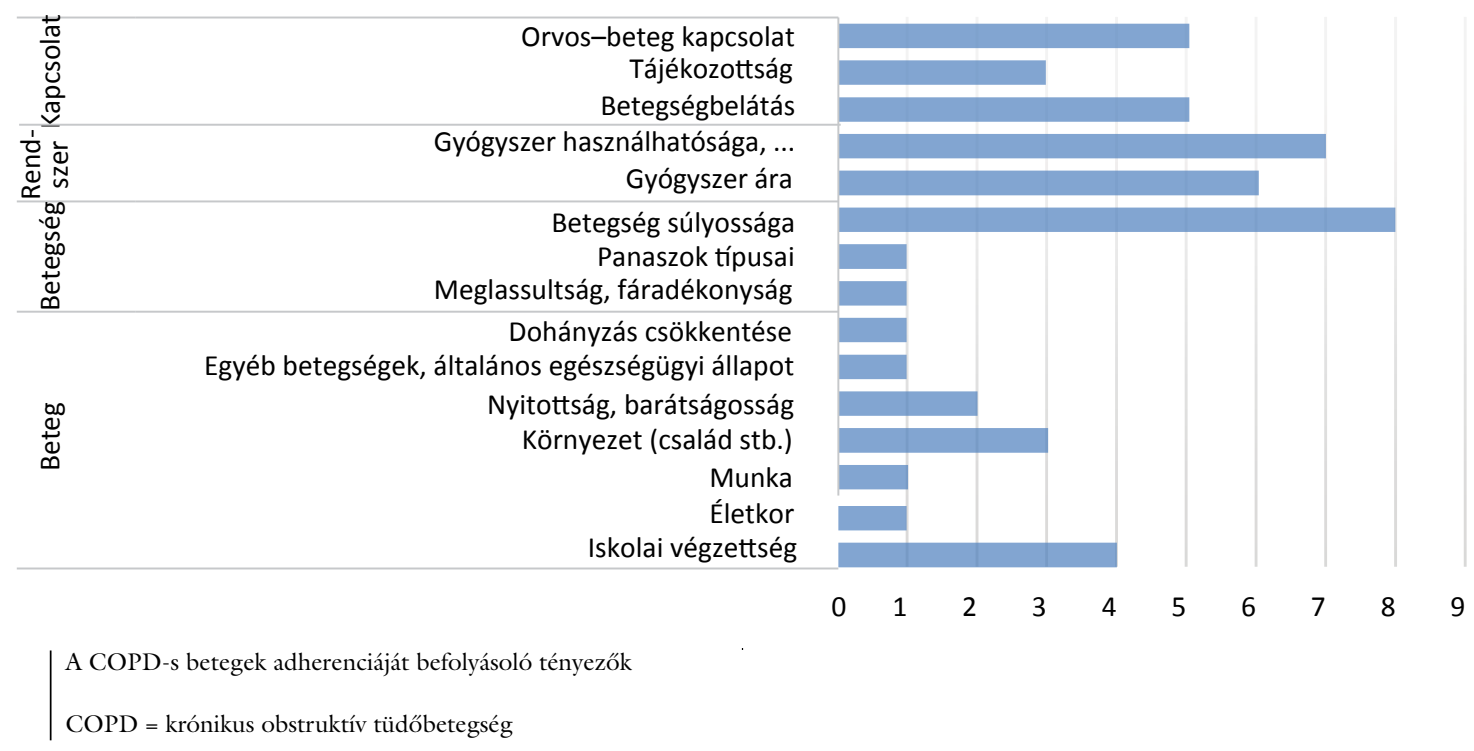


folyásoló szempontok között megjelenik még a gyógyszer ára és a beteg anyagi helyzete, ezt azonban trendszerúen kevesebbszer említették az interjúalanyok. Érdekes módon csupán egyetlen helyen jelentkezik a vezető tényezők között az inhalátor típusa.

A COPD és a dohányzás közötti kapcsolat megértése a betegségtudat kialakításában is fontos szerepet játszik, ez pedig hatással van az adherenciára is $[8,13]$. Az oktatás során arra kell számítanunk, hogy a betegek várhatóan egy alacsonyabb társadalmi skálán helyezkednek el, alacsonyabb iskolázottságúak és többségük férfi. A jelentkezés oka a tünetesség, az exacerbatio, a „családot zavarja" szempontok lesznek, várhatóan későbbi stádiumban történik. Szürőprogramokkal, az idősebb, (volt) dohányos korosztály tekintetében érdemes figyelemfelhívó és tudatosságnövelő oktatást tartani [14].

\section{Az oktatóprogram szempontjai}

Az oktatóprogram fejlesztéséhez szükséges betegképet az interjúk leírják. Elsődleges a dohányzásról való leszokás elősegítése, ennek prioritásként kell szerepelnie a programban $[14,15]$.

A személyes oktatás (tüdőgondozó, kórház vagy rehabilitációs centrum) preferált. Nem baj, ha az oktatás repetitív; tartalmaznia kell a betegség definícióját, a tünetek jellemzését, valamint tartalmazzon a gyógyszerhasználatról információt [16]. Szükséges, hogy a beteg nyelvezetét ismerje az oktatást végző személy, egyszerú és könnyen megjegyezhető [17], „meseszerü” elemeket használjon. A tüdőgyógyászok szerint kívánatos a gyakori kontroll, ezt eleinte havi, később háromhavi gyakorisággal tartják optimálisnak. Az egyik interjúalany személyes tapasztalata alapján: a program legyen hosszabb; és az elemei: tünetek, okok, kialakulás, tünettan, elvi terápiás lehetőségek, a gyógyszerhasználattal kapcsolatos technikai megfontolások és nehézségek, a komplikációk felmérése, teljes rehabilitáció. Ennek része a torna, úszásgyakorlat és relaxáció, egyhetes kúra formájában.

A betegekkel való viszony, kommunikációs paradigmák fontos szerepet játszanak a program sikerességében [18]. A fejlesztés során ezt a kérdést mindkét oldalról érdemes megvizsgálni: a betegoktatás mellett érdemes lehet olyan tréninget is kezdeményezni, amelyen az orvos kommunikációját javítjuk, és ezáltal a betegségbelátást javítjuk. Az egyik interjú különösen hangsúlyozza, hogy a beteggel töltött minőségi idő a fontos, és a beteg azt szeretné elsősorban, hogy emberszámba vegyék. Nem optimális ezért a telefonos oktatás, mivel azt gyakran személytelennek érzik, zaklatásnak vehetik, így az eredménye is mérsékeltebb lehet [19]. Fontos lehet még a türelemre intés és az életmódváltozás, hiszen a betegség sem rövid dohányzás alatt alakult ki, így a terápia is krónikusan alkalmazva hozhat eredményt. Az „életmódkódex" egyenesen arra vonatkozóan tesz ajánlást, hogy mit hogyan érdemes csinálni a tüdőbarát élet során, mi a teendő fulladás során, melyik gyógyszert mikor és ho- gyan kell használni. Ez a típusú partneri kommunikáció lehetôvé teszi, hogy a beteg maga tudatosabbá váljon, és kialakuljon benne a betegségmenedzsment szemlélete [18].

A betegek hozzáállásának javitása szintén fontos a hosszú távú hatások érdekében [20]. Ezt a szempontot valamennyi interjúalany kiemelte, ugyanakkor más-más irányvonalak mentén: a dohányzásról való leszokás, légzőgyakorlatok, kontroll és a gyógyszerek kiváltása, mozgás és a testsúly rendezése. Két interjúalany visszakapcsol az orvosi kommunikációhoz: az orvos küldjön pozitív visszajelzést, ha ezek bármelyike megtörtént, „ünnepelje a beteget". Az esélyadás kétoldalú: ha a beteg elfogadja a betegségét, és elhiszi, hogy az inhalátor tud neki segíteni, akkor ez már az első lépés a gyógyulás felé vezető úton [21]. A rehabilitációban való részvétel és az eredmények mindennapokba ültetése pedig megalapozza ennek a hosszú távú sikerét [22].

Az inhalátorral kapcsolatban elvárás, hogy használata egyszerúen megtanulható és gyorsan megtanítható legyen. Fontosnak tünik, hogy az inhalátor használatát kevés lépésben mutassuk be, ugyanakkor nyitottak mind a betegek, mind az orvosok az új megoldásokra is, ha látják a módszer előnyét [23]. A porbelégzőnél szükséges a minél jobb belégzőerő, többen úgy látják, hogy ez a módszer könnyebben kivitelezhető [17]. A betegek vizuálisan is szeretnek meggyőződni a hatásról. A spray-k tekintetében a koordinációt jelölték meg a tüdőgyógyászok mint aggályt, jelenleg itt tartják legalacsonyabbnak az adherenciát. Felmerült még az is, hogy az egyszeri adagolású szerek, bár könnyebben bevihetők, ha elmarad a napi adagolás, akkor az egész napi dózis kimaradt, ellenben a kétszeres adagolás esetén legalább részleges eredmény érhető el. Az adherencia magasabb az olcsó készítmények esetén, elsősorban a rövid hatású ß-agonistáknál és a muszkarinerg antagonistáknál és kombinációs készítményeiknél. A hosszú hatásúaknál viszont rosszabb, mivel a készítmények drágábbak, és a beteg nem érzi az instant hatást. Az interjúk alapján a betegoktatás tartalmára vonatkozó további összesítést az 5. ábra nyújt.

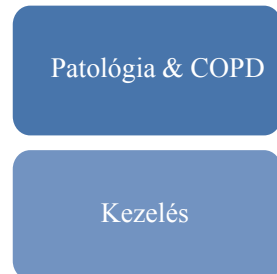

Mit jelent a COPD? Mit jelent számomra a „krónikus”?

Mi történik a tüdőmben az egészségeshez képest? - Jelek és tünetek

- Milyen elemei vannak a kezelésemnek? - Hogyan használjam helyesen a belégzömet? - Fenntartó és rohamoldó terápia

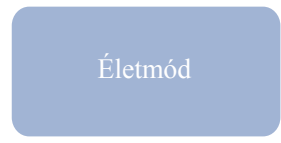

Mit okoz a dohányzás?

Légzési technikák és testtartás - Mikor kell felkeresni az orvosomat?

5. ábra $\mid \begin{aligned} & \text { Az oktatóprogram javasolt tartalma } \\ & \text { COPD = krónikus obstruktív tüdőbetegség }\end{aligned}$ 


\section{Megbeszélés}

A COPD-s betegek gondozásának és oktatásának kérdéseivel az irodalom részletesen foglalkozik. Ezek közül kiemelkednek a terápiahűséget és az informáltság magas szintjét elősegítendő programok, ezektől várható a legnagyobb siker [14, 22]. Az oktatás kapcsán nagy jelentőségú annak felismerése, hogy a betegnek milyen információra van szüksége, és mi az, amivel már rendelkezik [24]. Hosszú távon az a beavatkozás tud sikeres lenni, amely változást eredményez a beteg mindennapi életében [25], és amelynek hatására hajlandó a beteg olyan intervenciókat tenni a saját napi ritmusában, amelyek jobb betegségmenedzsmentet tesznek lehetôvé [16]. Ez ideálisan integrált szemléletben történik, vagyis elsősorban a tüdőgyógyász végzi a betegellátást, másodsorban pedig a háziorvos és a gyógyszerész vesz részt a gondozásban $[12,26]$.

A célkitűzésben kijelölt célokat a tanulmánynak sikerült elérnie, és az interjúk eredményeit figyelembe véve az oktatóprogram fejlesztése során az alábbi szempontokat érdemes megfontolni.

1) A betegkép szerint a tüdőgyógyászok alulszocializált, fulladó, köhögős, dohányzó, férfi betegekkel találkoznak. Az oktatóanyag szempontjából ez azt jelenti, hogy egyszerü nyelvezetet, a betegek által használt szavakat érdemes használni. Ha olyan információs brosúra készül, amelyen egy mintabeteg is szerepel, érdemes idősebb férfit választani.

2) A betegek oktatását érdemes az alapoknál kezdeni, így szükséges a COPD betûszó magyarázata, különösen annak megértése, hogy ez krónikus állapot (ez összhangban van azzal, hogy el kell különíteni az asztmától, nem hagyható abba a terápia, ha jobban van a beteg). Meg kell érteni a dohányzás és a COPD közötti összefüggést és elősegíteni a dohányzásról való leszokást. Az „éberség” kialakítása és a korai diagnózis érdekében érdemes a kockázati csoport tagjait is bevonni (ez összhangban van az alacsony diagnosztizáltsággal és a késői jelentkezéssel).

3) A tünetek közül a fáradékonyság, a köhögés, a fulladás emelhető ki, ezeket társítani kell a beteg fejében a betegséggel; a kezelés magyarázása során be kell mutatni, hogy a terápia hogyan oldja meg ezeket a tüneteket (ez összhangban van a betegségbelátás hiányáról írtakkal). Fontos tudnia a betegnek, hogy melyik gyógyszer rohamoldó, és melyik a fenntartó terápia része (ennek szükségére utal az interjúkban a terápiával kapcsolatos alacsony adherencia, amely számtalan alkalommal megjelenik).

4) Az oktatás során fel kell eleveníteni a helyes adagolást és gyakoriságot, valamint az inhalátorhasználatra vonatkozó ismereteket. A roham kezelése és az orvos felkeresése is megemlítendő itt: a „bagatellizálás” miatt sokan csak későn és nagyon rossz állapot esetén jelentkeznek.
5) A kétirányú, nyílt kommunikáció és a bizalom szintén megjelent az interjúkban; ez inkább már az oktatást végző módszereire vonatkozik: szükség van együttműködésre, hogy „ünnepelje a beteget” a kívánt eredmény elérése esetén. Ezenkívül érdemes lehet egy olyan kommunikációs tréning az orvos részére, amely a betegségelfogadást és az azzal való megküzdést segíti eló a betegnél.

Az adherencia tekintetében a tanulmány kvalitatív információi megfelelnek a nemzetközi irodalomban talált értékeknek, elsősorban a kombinációs terápiára vonatkozóan (a nem megfelelő adherencia értékei 50-70\% között szórnak [18]). A nagy szórás egyébként jellemző az összefoglaló tanulmányok tekintetében is [27], valamint Magyarországról származó hasonló tanulmány [28] szerint az optimális adherenciával rendelkező COPD-sek aránya $60 \%$ körüli: ez jóval pozitívabb érték, mint ami az interjúkból körvonalazódik. Az egészen biztos, hogy felügyelet mellett és klinikai vizsgálatokban sokkal magasabb adherenciával lehet számolni [27], tehát az oktatás várhatóan pozitívan befolyásolja az adherenciát $[22,25]$.

\section{Következtetések}

Az interjúk szerint a COPD-s betegek oktatására nagy szükség van. Érdemes ezt strukturáltan, a szakorvosok tapasztalatát felhasználva, a beteg nyelvezetének és tudásszintjének megfelelően megtenni [29]. A fentiekben bemutattuk a COPD diagnosztizáltságával, az orvos betegképével, a beteg adherenciájával és az inhalátorral kapcsolatos attitüdöket.

A kutatást érdekes lenne továbbfejleszteni: magasabb elemszám, a betegek körében hasonló vizsgálat végzése, valamint a kérdéskör kiterjesztése az életminőség, illetve az életminőség és az adherencia átfedő témáira mindmind érdekes szempontok.

Összegzésként elmondhatjuk, hogy a COPD kezelése során a betegoktatás kiemelt jelentőségű. A cikk tanulságait figyelembe véve érdemes a helyi körülményekre szabva egy olyan oktatóprogramot fejleszteni, amely figyelembe veszi az érdekelt felek igényeit [30].

Anyagi támogatás: A közlemény megírása anyagi támogatásban nem részesült.

Szerzői munkamegosztás: O. M.: Tervezés, adatgyüjtés, elemzés, a kézirat szövegezése. K. Sz.: A diagramok elkészítése, a hozzájuk tartozó statisztikai részek megírása és a félkvantitatív elemzés. K. Cs.: Adatgyưjtés. P.-F. D.: A kézirat átnézése. Cs. E.: Adatgyưjtés, a kézirat átnézése, javítása. M. Á.: Tervezés, a kézirat átnézése, javítása, jóváhagyása. A cikk végleges változatát valamennyi szerző elolvasta és jóváhagyta.

Érdekeltségek: A szerzőknek nincsenek érdekeltségeik. 


\section{Irodalom}

[1] Cazzola M, Donner CF, Hanania NA. One hundred years of chronic obstructive pulmonary disease (COPD). Respir Med. 2007; 101: 1049-1065.

[2] Hattab Y, Alhassan S, Balaan M, et al. Chronic obstructive pulmonary disease. Crit Care Nurs Q. 2016; 39: 124-130.

[3] Pleasants RA, Ohar JA, Croft JB, et al. Chronic obstructive pulmonary disease and asthma-patient characteristics and health impairment. COPD 2014; 11: 256-266.

[4] Cramer JA, Roy A, Burrell A, et al. Medication compliance and persistence: terminology and definitions. Value Health 2008; 11 : 44-47.

[5] World Health Organization. Adherence to long-term therapies: evidence for action. WHO, Geneva, 2003. Available from: https://www.who.int/chp/knowledge/publications/adherence_ report/en/.

[6] Chakrabarti S. What's in a name? Compliance, adherence and concordance in chronic psychiatric disorders. World J Psychiatry 2014; 4: 30-36.

[7] Kontz K, Tomisa G, Szenasi G, et al. Characteristics of medical care of asthma and COPD patients in the Hungarian healthcare system. [Asztmás és COPD-s betegek ellátásának jellemzői a magyar egészségügyben.] Med Thorac. 2016; 69: 243-251. [Hungarian]

[8] Bunker JM, Reddel HK, Dennis SM, et al. A pragmatic cluster randomized controlled trial of early intervention for chronic obstructive pulmonary disease by practice nurse-general practitioner teams: study protocol. Implement Sci. 2012; 7: 83.

[9] Mannino DM, Buist AS. Global burden of COPD: risk factors, prevalence, and future trends. Lancet 2007; 370: 765-773.

[10] Rosenthal M. Qualitative research methods: why, when, and how to conduct interviews and focus groups in pharmacy research. Curr Pharm Teach Learn. 2016; 8: 509-516.

[11] Kovács G. Pulmonology. [Tüdőgyógyászat.] 2016. Available from: http://medicalonline.hu/gyogyitas/cikk/ tudogyogyaszat_2016. [accessed: September 1, 2019]. [Hungarian]

[12] Seemungal TA, Wedzicha JA. Integrated care: a new model for COPD management? Eur Respir J. 2006; 28: 4-6.

[13] Fan J, Wang N, Fang LW, et al. Awareness of knowledge about chronic obstructive pulmonary disease and related factors in residents aged 40 years and older in China, 2014. Zhonghua Liu Xing Bing Xue Za Zhi 2018; 39: 586-592. [Article in Chinese]

[14] GOLD. Global strategy for the diagnosis, management and prevention of chronic pulmonary obstructive disease. Global Iniative for Chronic Obstructive Lung Disease Inc. 2018. Available from: https://goldcopd.org/wp-content/uploads/2017/11/ GOLD-2018-v6.0-FINAL-revised-20-Nov_WMS.pdf [accessed: September 12019$]$.

[15] Guilleminault L, Rolland Y, Didier A. Characteristics of nonpharmacological interventions in the elderly with COPD. Smoking cessation, pulmonary rehabilitation, nutritional management and patient education. Rev Mal Respir. 2018; 35: 626-641. [Article in French]

[16] Tzortziou Brown V, Patel I, Thomas N, et al. New ways of working; delivering better care for people with long-term conditions. London J Prim Care (Abingdon) 2017; 9: 60-68.

[17] García-Río F, Soler-Cataluña J, Alcazar B, et al. Requirements, strengths and weaknesses of inhaler devices for COPD patients from the expert prescribers' point of view: results of the EPOCA Delphi Consensus. COPD 2017; 14: 573-580.

[18] Rogliani P, Ora J, Puxeddu E, et al. Adherence to COPD treatment: myth and reality. Respir Med. 2017; 129: 117-123.

[19] Cameron-Tucker H, Wood-Baker R, Joseph L, et al. A randomized controlled trial of telephone-mentoring with homebased walking preceding rehabilitation in COPD. Int J Chron Obstruct Pulmon Dis. 2016; 11: 1991-2000.

[20] Nakken N, Janssen DJ, van den Bogaart EH, et al. Knowledge gaps in patients with COPD and their proxies. BMC Pulm Med. 2017; 17: 136

[21] Enocson A, Jolly K, Jordan RE, et al. Case-finding for COPD in primary care: a qualitative study of patients' perspectives. Int J Chron Obstruct Pulmon Dis. 2018; 13: 1623-1632.

[22] Corhay JL, Dang DN, van Cauwenberge H, et al. Pulmonary rehabilitation and COPD: providing patients a good environment for optimizing therapy. Int J Chron Obstruct Pulmon Dis. 2014; 9: 27-39.

[23] Hawken N, Torvinen S, Neine ME, et al. Patient preferences for dry powder inhaler attributes in asthma and chronic obstructive pulmonary disease in France: a discrete choice experiment. BMC Pulm Med. 2017; 17: 99.

[24] Grover A, Joshi A. An overview of chronic disease models: a systematic literature review. Glob J Health Sci. 2014; 7: 210-227.

[25] Partridge MR, Dal Negro RW, Olivieri D. Understanding patients with asthma and COPD: insights from a European study. Prim Care Respir J. 2011; 20: 315-323.

[26] Nici L, ZuWallack R. Integrated care in chronic obstructive pulmonary disease and rehabilitation. COPD 2018; 15: 223-230.

[27] López-Campos JL, Quintana Gallego E, Carrasco Hernández L. Status of and strategies for improving adherence to COPD treatment. Int J Chron Obstruct Pulmon Dis. 2019; 14: 1503-1515.

[28] Ágh T, Inotai A, Mészáros Á. Factors associated with medication adherence in patients with chronic obstructive pulmonary disease. Respiration 2011; 82: 328-334.

[29] Heaney LG, McGarvey LP. Personalised medicine for asthma and chronic obstructive pulmonary disease. Respiration 2017; 93: 153-161.

[30] Chuang C, Levine SH, Rich J. Enhancing cost-effective care with a patient-centric chronic obstructive pulmonary disease program. Popul Health Manag. 2011; 14: 133-136.

(Oláh Máté dr., Budapest, Hőgyes Endre u. 9., 1092 e-mail: mate.olah@gmail.com)

A cikk a Creative Commons Attribution 4.0 International License (https://creativecommons.org/licenses/by/4.0/) feltételei szerint publikált Open Access közlemény, melynek szellemében a cikk bármilyen médiumban szabadon felhasználható, megosztható és újraközölhető, feltéve, hogy az eredeti szerző és a közlés helye, illetve a CC License linkje és az esetlegesen végrehajtott módositások feltüntetésre kerülnek. (SID_1) 